\title{
Parameters affecting the enhanced permeability and retention effect: the need for patient selection
}

Article

Accepted Version

Creative Commons: Attribution-Noncommercial-No Derivative Works 4.0

Natfji, A. A., Ravishankar, D., Osborn, H. M. I. and Greco, F. (2017) Parameters affecting the enhanced permeability and retention effect: the need for patient selection. Journal of Pharmaceutical Sciences, 106 (11). pp. 3179-3187. ISSN 0022-3549 doi: https://doi.org/10.1016/j.xphs.2017.06.019 Available at https://centaur.reading.ac.uk/72672/

It is advisable to refer to the publisher's version if you intend to cite from the work. See Guidance on citing.

To link to this article DOI: http://dx.doi.org/10.1016/j.xphs.2017.06.019

Publisher: Elsevier

All outputs in CentAUR are protected by Intellectual Property Rights law, including copyright law. Copyright and IPR is retained by the creators or other copyright holders. Terms and conditions for use of this material are defined in the End User Agreement.

www.reading.ac.uk/centaur 
Central Archive at the University of Reading

Reading's research outputs online 


\title{
Parameters affecting the enhanced permeability and retention effect: the need for patient selection
}

\author{
Az Alddien Natfji, Divyashree Ravishankar, Helen M. I. Osborn, Francesca Greco ${ }^{1}$ \\ Reading School of Pharmacy, Univer sity of Reading, Whiteknights, Reading, RG6 6AD, \\ UK.
}

\begin{abstract}
The enhanced permeability and retention (EPR) effect constitutes the rationale by which nanotechnologies selectively target drugs to tumors. Despite promising pre-clinical and clinical results, these technologies have, in our view, underachieved compared to their potential, possibly due to a suboptimal exploitation of the EPR effect. Here, we have systematically analyzed clinical data to identify key parameters affecting the extent of the EPR effect. An analysis of 17 clinical studies showed that the magnitude of the EPR effect was varied and was influenced by tumor type and size. Pancreatic, colon, breast, and stomach cancers showed the highest levels of accumulation of nanomedicines. Tumor size also had an effect on the accumulation of nanomedicines, with large size tumors having higher accumulation than both medium- and very large- sized tumors. However, medium tumors had the highest percentage of cases ( $100 \%$ of patients) with evidence of the EPR effect. Moreover, tumor perfusion, angiogenesis, inflammation in tumor tissues, and other factors also emerged as additional parameters that might affect the accumulation of nanomedicines into tumors. At the end of the commentary, we propose two strategies for identification of suitable patient sub-populations, with respect to the EPR effect, in order to maximize therapeutic outcome.
\end{abstract}

Keywords: cancer; targeted drug delivery; prodrugs; nanotechnology; pharmacokinetics;

\section{INTRODUCTION}

In the 1980s, Maeda and his group reported for the first time that a polymer-protein conjugate (a conjugate of styrene maleic anhydride and neocarzinostatin, SMANCS) accumulated preferentially in tumors ${ }^{1}$. They attributed this

${ }^{1}$ Correspondence to: Francesca Greco (E-mail: f.greco@reading.ac.uk) 
phenomenon to the combination of increased extravasation (enhanced permeability) and decreased drainage by the lymphatic system (enhanced retention), and defined it 'the enhanced permeability and retention' (EPR) effect. At the time, a number of nanotechnologies (Fig. 1) had already been proposed and/or had been developed. Liposomes had been discovered in the mid 1960s, while polymer-drug conjugates had been proposed in the $1970 \mathrm{~s} .{ }^{2,3}$ The discovery of the EPR effect gave a much stronger rationale to the use of these nanotechnologies for cancer.

Thirty years since the discovery of the EPR effect, nanotechnologies applied to medicines are expanding, with the number of publications including nanomedicines and cancer (Web of Science, topic) increasing over the last 10 years (Fig. 2), with a number of these being on the market for this therapeutic application (examples among polymer-protein conjugates include SMANCS and Oncaspar ${ }^{\mathbb{B}}$; and for liposomes, see Doxil ${ }^{\circledR}$, Marqibo ${ }^{\circledR}$, and Onivyde $\left.{ }^{\circledR}\right) .{ }^{4}$ However, it could also be argued that nanotechnologies have under-delivered on their original promise and the only polymer-drug conjugate on the market (Movantik ${ }^{\circledR}$, Naloxegol, PEGylated naloxol) is marketed for non-cancer applications. ${ }^{5}$

The study of Maeda et al, and subsequent studies, described the specific physiological characteristics of tumor blood vessels. Research in this field documented that the angiogenic blood vessels in many solid tumors are pathologically disorganized and have impaired lymphatic drainage, which leads to defects in tumor blood vessel architecture. This defect significantly enhances the release of large amounts of vascular permeability factors that, in turn, increase the permeability of tumor blood vessels to secure sufficient nutrition and oxygen supply required for cancer growth. ${ }^{6,7}$ The hyper-permeability of tumor vasculature, and the lack of lymphatic drainage, allow the passive and relatively selective accumulation of extravasated large molecules including proteins, liposomes, polymer-drug conjugates, micelles, and other nanoparticles in tumor tissues and reduces their clearance from the targeted tissues. ${ }^{8,9}$

These pathophysiological features of tumor blood vessels have made the EPR effect a valuable targeting mechanism for cancer, where the aim is to allow nanocarriers to selectively enter tumor cells with no, or less, systemic side effects than those that are normally associated with conventional chemotherapeutic agents. 10-12 Thirty years of research on the EPR effect are highlighting that this is a complex phenomenon. Indeed, recent studies showed that this effect is much more heterogeneous than previously considered. ${ }^{13-15}$

In particular, the influences of the size and tumor type on the magnitude of the EPR effect have been reported in different in vivo studies. ${ }^{8,16}$ Many studies have suggested that the most important factors that may influence the EPR and its magnitude are: (i) the vasculature characteristics of the tumor tissue, (ii) the tumor 
type, size, and location (iii) the patient's characteristics including gender, age, and body composition. ${ }^{17,18}$

In this commentary, clinical data relating to the EPR effect are analyzed, and the key parameters that control this phenomenon are highlighted. Particular focus is given to determining factors that might guide patient selection for better utilization of the EPR strategy in cancer care.

\section{EPR MAGNITUDE AND TUMOR TYPE}

The first aspect considered in this study was to investigate the relationship between tumor type and the magnitude of the EPR effect. A systematic search was carried out using established search engines (Pubmed, Web of Science, and Science Direct) and the procedure is summarized in (Fig. 3). From the search, 24 studies ${ }^{19-}$ ${ }^{42}$ were identified which met the inclusion criteria, namely: (a) related to nanomedicine, (b) contained clinical data (c) related to solid tumors (d) contained data related to the magnitude of the EPR effect (either quantitative or qualitative). Data from these studies were assembled and analyzed as presented in (Fig. 4). As the various studies used different techniques to quantify tumor accumulation (e.g. radio-labeling, detection by electron microscopy (EM), and chemical analysis), to allow a comparison, when possible (i.e data available), data were expressed as ratios (tumor/normal tissue content, $\mathrm{T} / \mathrm{N}$ ratio), and normalized to account for the different sample size. A high ratio of tumor to normal tissue content of nanomedicines was considered indicative of their accumulation in tumor tissues, as a consequence of the EPR effect.

From (Fig. 4), six tumor types displayed the highest levels of normalized $\mathrm{T} / \mathrm{N}$ ratios of nanomedicine accumulation in comparison with other tumors. They were: i) pancreatic adenocarcinoma, ii) colon, colorectal, and rectal cancers, iii) breast cancers, iv) stomach cancer, v) brain cancer and brain metastases, vi) ovarian cancer. Similar results were found in our previous study, ${ }^{13}$ which, however, was largely qualitative and combined clinical with preclinical studies and contained data from a smaller sample of clinical studies (9 studies), where the accumulation of the nanomedicines and the EPR effect was observed in breast, ovarian, and lung cancers. Interestingly, another recent study analyzed retrospectively the accumulation of nanoparticles in animal models. This identified skin, pancreas, brain, and liver tumors as the types of tumors which had the highest $\%$ injected dose reaching the tumor $(1.3,0.8,0.8,0.7$, respectively), with breast, cervix, prostate and colon, following at $0.6 \% .{ }^{43}$ While comparing different studies and different methodologies can be challenging and lead to incorrect conclusions, these works raise the issue of the validity of animal models to represent the EPR in clinical scenarios. Indeed, one may think of many reasons why animal models do 
not fully represent the clinical scenarios. The location, in which the xenograft is implanted, is driven more by the practical feasibility of scientists than their intention to mimic the actual site of the tumor. Therefore, the implanted xenografts usually lack tumor-stroma interaction, and consequently, they exhibit somewhat 'artificial interaction' between the surrounding environment and the implanted tumor. This could greatly influence the accumulation of nanomedicines within these tissues and may not reflect their real behavior. Moreover, some anticancer agents are effective only against specific tumors, which does not allow the correct extrapolation of data from animal models. ${ }^{44,45}$ These and other factors are extensively discussed in another commentary. ${ }^{46}$

It should also be noted that when looking at individual studies, a level of variability is found within a single tumor type, which can be very significant. ${ }^{13}$ $\operatorname{Doxil}^{\circledR} /$ Caelyx $^{\circledR}$ (PEGylated doxorubicin liposomes) has been used clinically to treat different tumors (e.g. metastatic breast cancer, ovarian cancer). In a study on patients diagnosed with primary glioblastoma and treated with radiolabeled Caelyx ${ }^{\circledR}, \mathrm{T} / \mathrm{N}$ count ratio range was $13-19$, while in metastatic brain tumor, patients showed $\mathrm{T} / \mathrm{N}$ count ratio range of $7-13$, and $40 \%$ of the patients with metastatic brain tumor showed a complete response. A partial response was also detected in $40 \%$ of those patients, which would suggest that enough amount of the liposomes had reached the tumor. ${ }^{19}$ In another clinical study using a nanoemulsion containing paclitaxel to treat breast cancer, the EPR effect was observed but the extent varied (T/N ratio ranged from 2.3- 4.7). ${ }^{27}$ Similarly, the EPR effect was documented for an HPMA conjugate of doxorubicin (PK1) in breast cancer but with some variability, with $1.8 \%$ and $5.9 \%$ of the injected dose accumulating in the tumors of two patients. ${ }^{26}$ There were also instances in which a very high tumor accumulation was observed in single patients. For example, in a study with LipoPlatin $^{\circledR}$ (liposomal Cisplatin), elevated levels of Pt have been detected in colon cancer tissues, where the average $\mathrm{T} / \mathrm{N}$ ratio of $\mathrm{Pt}$ in a patient with 2 cancerous lesions was $172.2 .^{34}$

Interestingly, of all the tumor types for which data were available, only two (cholangio and oesophageal carcinoma) displayed no evidence of the EPR effect (i.e. normalized $\mathrm{T} / \mathrm{N}$ ratio $\leq 1$ ) and in both cases, data were only available from one study, on one patient ${ }^{31}$ (Fig. 4).

\section{EPR MAGNITUDE AND TUMOR SIZE}

Another factor that others have reported to affect the extent of the EPR effect is tumor size. ${ }^{8,47,48}$ However, studies reporting these correlations have mainly been based on animal models used to mimic the EPR effect, while limited studies have 
systematically examined the influence of tumor size on the magnitude of the EPR effect. Therefore, in an attempt to establish quantitative relationships between the EPR effect and tumor size, here we looked at clinical data for normalized T/N ratios for tumors of different sizes (Fig. 5). It should be pointed out at the outset that most clinical studies on nanomedicines are carried out in patients with advanced (or fairly advanced) disease states. Indeed, we were unable to find any clinical studies on patients with small localized cancers (stage 1). Therefore, tumors were arbitrarily categorized depending on their stages or sizes into medium, large, and very large size tumors. Tumors were defined as follows: 'medium' if of stage $\leq \mathrm{IIB}$ and/or if area $\leq 25 \mathrm{~cm}^{2}$; 'very large' if they were on advanced stages (i.e. IIB/V stage, recurrent, unresectable, metastatic, etc) and/or if area $\geq 140 \mathrm{~cm}^{2}$. Large size tumors were in between the previous sizes.

Tumors with large size showed the highest normalized $\mathrm{T} / \mathrm{N}$ accumulation ratios of nanomedicines of 27.6, while medium and very large size tumors had normalized T/N accumulation ratios of 4 and 5.4, respectively. The magnitude of the EPR effect seemed to increase when the tumor size increased, then seemed to decrease above a certain size threshold (from large to very large). However, it is important to note that when the same data were analyzed with respect to the percentage of patients that have at least a normalized $\mathrm{T} / \mathrm{N}$ ratio of $\geq 2$, the data appeared quite different with the smaller type of tumors having the highest proportion of patients with tumors displaying the EPR effect (virtually 100\%). The normalized $\mathrm{T} / \mathrm{N}$ ratio of $\geq 2$ was arbitrarily chosen to highlight patients with a significant accumulation of nanomedicine within tumor tissue i.e. 2 folds greater accumulation comparison to the surrounding tissues. The proportions of large and very large tumors showing a normalized $\mathrm{T} / \mathrm{N}$ ratio of $\geq 2$ were $53 \%$ and $67 \%$, respectively. This revealed that large tumors had a lot of accumulation of nanomedicines in comparison with other tumors, but only $53 \%$ of patients with these tumors displayed this effect. This indicates that large tumors may have high levels of accumulation of nanomedicines but with more heterogeneity of the EPR effect.

In light of the previous information and other information from in vivo and clinical studies, it is difficult to identify the correlation between tumor size and EPR effect. In an in vivo study using nude mice bearing human head and neck cancer xenografts, small tumors showed the highest level of accumulation in comparison with other tumor sizes, and tumor uptake levels of the radiolabeled liposomes were inversely proportional to the tumor weight. ${ }^{49}$ These findings are in line with another in vivo study, where the accumulation of HPMA-Dox conjugate (PK1, FCE28068) was size-dependent in half of tested tumors; small tumors showed greatest uptake levels. ${ }^{8}$ Clinically, in HNC patients with average tumor 
size of $36.2 \pm 18 \mathrm{~cm}^{3}$, the uptake of radiolabeled liposomes was approximately 2 and 7 fold more than the uptake in patients with NSCLC and breast cancers, respectively (their tumor sizes were $114.5 \pm 42 \mathrm{~cm}^{3}$ and $234.7 \pm 101.4 \mathrm{~cm}^{3}$ respectively). ${ }^{23}$ However, in another in vivo study, the influence of tumor size on the uptake of radiotracer uptake was limited. ${ }^{50}$ This was explained by the ability of small tumors to secrete proangiogenic factors and to have necrotic regions and networks of well-developed microvessels. ${ }^{51-53}$ This was in line with another clinical study, where the size of the sarcoma did not clearly affect the accumulation of radiolabeled Caelyx ${ }^{\circledR}$ in tumor tissues. ${ }^{41}$ It is noteworthy to highlight that the influence of the previous treatments/therapeutic cycles (such as chemotherapy, radiotherapy, and other treatments) on tumor size or condition was not considered in the analysis of clinical studies, as data were not available. However, most of the studies mentioned avoiding of temporal overlap with previous therapeutic cycles (typically at least a 3-4-week gap from the previous treatment).

The lack of clinical data about the exact location of tumors has not allowed us to systematically assess the impact of this parameter on the accumulation of nanomedicines within the tumor tissues. However, in the pool of analyzed data, we observed that the accumulation of LipoPlatin ${ }^{\mathbb{B}}$ varied according to the site of the tumor, where the $\mathrm{T} / \mathrm{N}$ ratio of $\mathrm{Pt}$ in two specimens taken from different locations of the stomach of the same patient ranged from 10 to $40 .{ }^{34}$ Potentially, it is important to consider the influence of this factor on the magnitude of the EPR effect.

Although documentation of the effect of tumor size and location on the tumor accumulation of nanomedicines is limited, their impact on the magnitude of the EPR effect could be another factor that may explain why some tumors are more clinically responsive to the treatment with nanomedicines than other tumors.

\section{IMPACT OF TUMOR PERFUSION ON THE EPR EFFECT}

\section{Tumor angiogenesis and tumor perfusion}

As nanomedicines are carried to tumor tissues by the blood, it is intuitive that the magnitude of the EPR effect can potentially depend on tumor perfusion. Therefore, in this section, the influence of tumor perfusion on the magnitude of the EPR effect is analyzed. Angiogenesis is the process that tumors use to form new blood vessels and it is controlled by the secretion of the potent cytokine VEGF. ${ }^{54}$ However, the presence of new blood vessels in tumors does not necessarily correlate with an increased perfusion. For example, it has been reported that the secretion of VEGF in renal tumor tissues was 3-37 fold that in found normal renal parenchyma ${ }^{55}$. 
However, the mean tumor perfusion was $0.97 \pm 0.49 \mathrm{~mL} / \mathrm{mL} / \mathrm{min}$, which was significantly lower than that in normal tissues $(1.81 \pm 0.48 \mathrm{~mL} / \mathrm{mL} / \mathrm{min}) .{ }^{56}$ This lack of direct correlation between angiogenesis in tumors and perfusion is most likely due to the heterogeneity of the tumor vasculatures (Fig. 6). Similar findings were found in other types of tumors such as lung carcinoma and transplanted hepatoma (in vivo) ${ }^{57}$ and pancreatic tumors (a clinical study). ${ }^{58}$ Interestingly, the use of antiangiogenic therapy was reported to enhance the sensitivity of tumor tissues towards chemotherapy as it enhanced tumor perfusion by shrinking tumor vasculature which resulted in improved tumor perfusion and drug uptake. ${ }^{59}$

Therefore, understanding how the EPR effect varies according to human tumor blood flow $(\mathrm{BF})$, and how this reflects on the localization of nanomedicines within tumor tissues, would allow a more appropriate use of nanomedicines and enhance their clinical outcomes.

\section{Effect of tumor type on tumor perfusion}

Tumors have different BF patterns, and their BF also differs from that in the surrounding normal tissues. This variation has affected the delivery of chemotherapeutic agents (including nanomedicines) to these tissues, and thus their efficacy. ${ }^{60}$ We identified 10 studies ${ }^{58,61-69}$ reporting data on blood perfusion in tumor tissues and in adjacent normal tissues, which allows calculation of T/N BF ratios. Table 1 summarizes the data per tumor type, stage, size, and location, when available. For breast cancer, 2 studies were available which both reported similar levels of T/N BF ratio ( $\sim 5$ ). This could be a possible explanation for the fact that breast cancer is one of the tumor types associated with high normalized $\mathrm{T} / \mathrm{N}$ accumulation ratio. Similar considerations can be applied to colorectal cancer (T/N $\mathrm{BF}$ ratio $\geq 2$ ). For other tumors (e.g. pancreatic tumors), drawing a conclusion is more complex as there was a level of variability in tumor perfusion among different studies (e.g. T/N BF ratio ranged from 0.27 to 2.24 in pancreatic tumors ${ }^{58,67}$ ) and the perfusion might be influenced by tumor size, stage, and location.

\section{Effect of inflammation and tumor perfusion}

There are pathological and physiological states that affect BF, and one such state is inflammation. Interestingly, increased BF is, indeed, a cardinal feature of inflamed tissues. ${ }^{70}$ Therefore the presence of inflammation in some tumors may be responsible for their enhanced perfusion. ${ }^{71,72}$ In addition, the co-presence of other disease states (co-morbidity) also can affect inflammation levels and subsequent $\mathrm{BF}$ in tumors. For example, it has been reported that the BF in HNC tumors with human papillomavirus infection (HPV) was higher than that in HPV-negative 
tumors, which assumes that the inflammation accompanying the infection was responsible for their elevated $B \mathrm{BF}^{73}$ These data were in line with other animal studies which reported high localization of liposomes in inflamed tissues when compared with normal tissues. ${ }^{74-76}$ Another clinical study has shown that inflamed HNC and NSCLC had increased uptake levels of liposomes in comparison with a non-inflamed breast cancer which could be potentially linked to an increased BF in tumor tissues due to inflammation. ${ }^{23}$ However, it should also be noticed that tumor types and sizes in this study were also different.

\section{CONSIDERATION OF OTHER FACTORS AFFECTING THE CLINICAL APPLICATION OF NANOMEDICINES:}

The EPR effect is the key rationale for applying nanomedicines to tumor tissues. This commentary has focused entirely on it. However, the EPR effect is one of several additional factors that have a key impact on the therapeutic activity of nanomedicines. ${ }^{77-82}$ The whole process is summarized in (Fig. 7).

\section{PROPOSED STRATEGIES}

In this paper, we have highlighted how the EPR effect is affected by a number of factors which result in a high patient to patient variability in its magnitude.

Appropriate patient selection is a key factor for the efficacy of therapy, and indeed, is carried out routinely in clinical settings (e.g. HER-2 screening prior to Herceptin use). As nanosized drug delivery systems rely on the EPR effect for activity, patient selection based on the magnitude of the EPR effect would be a logical step. However, this has, to date, been largely overlooked. Here, we indicate two possible strategies that could be used in the future to achieve rational administration of nanomedicines, both of which rely on identification of a patient sub-population in which the EPR effect is well expressed. These two strategies are summarized in (Fig. 8).

The first possible strategy (Fig. 8A) consists of systematically producing radiolabeled analogs of each nanomedicine reaching the market place for cancer applications. Within this strategy, a radiolabeled analog of the nanomedicine could be given to a cohort of cancer patients individually, and its accumulation quantified in every patient. Patients showing evidence of accumulation (EPR + ve group) could then be treated with the nanomedicine, following standard protocols, while the patients with no evidence/or suboptimal level of nanomedicine accumulation could be moved to a different type of treatment. A similar approach has been used 
in very early studies on polymer-drug conjugates, when researchers were still looking for evidence of the EPR effect (see the studies of radiolabeled HPMA copolymer-doxorubicin analogues ${ }^{24}$ ). Here we are proposing to systematically carry out these studies with the purpose of patient selection for suitability of the treatment.

The second strategy we propose (Fig. 8B) consists of carrying out an extensive research program to identify possible biomarkers as predictors for the EPR effect. If such biomarkers were identified, prospective patients could be prescreened individually and only the sub-population showing the presence (or appropriate levels) of the suitable biomarkers for the EPR effect (EPR +ve patients) could then be treated with nanomedicines, while the others could follow alternative therapeutic approaches.

\section{CONCLUSIONS}

In conclusion, this commentary has highlighted the complexity of the EPR phenomenon and the key factors that influence its magnitude. Different factors have been shown to be important, and these include tumor features such as vasculature, type, and size, as well as patient characteristics. Tumor BF was also identified as an important factor. Moreover, other factors have been shown to play a critical role in the accumulation of nanomedicines within the tumor tissues. However, it is hard to provide a definite conclusion on the type of nanomedicine as a promising drug delivery system at least in the current period. This is due to the involvement of several factors that influence the characterization of nanomedicines and their activity, coupled with patient to patient variations, which eventually affect the extent of the EPR effect. In our view, it is crucial to establish a prescreening mechanism that allows appropriate patient selection for macromolecular systems relying on the EPR effect, in order to maximize their accumulation within tumor tissues. However, one should be aware of the fact that even if the proposed strategy was successful in achieving this objective for a particular nanomedicine, there are other factors (mentioned above and in (Fig. 7)) that might affect the overall clinical outcomes.

\section{ACKNOWLEDGEMENT}

The authors would like to thank the University of Reading and CARA (Council for At-Risk Academics) for providing an academic placement to AAN and for their financial support. 


\section{REFERENCES}

1. Matsumura Y, Maeda H. 1986. A new concept for macromolecular therapeutics in cancer chemotherapy: mechanism of tumoritropic accumulation of proteins and the antitumor agent smancs. Cancer Res 46(12 Pt 1):6387-6392.

2. Duncan R. 2014. Polymer therapeutics: Top 10 selling pharmaceuticals - what next? J Control Release 190:371-380.

3. Gregoriadis G. 2008. Liposome research in drug delivery: the early days. J Drug Target 16(7):520-524.

4. Perez-Herrero E, Fernandez-Medarde A. 2015. Advanced targeted therapies in cancer: Drug nanocarriers, the future of chemotherapy. Eur J Pharm Biopharm 93:52-79.

5. Prichard D, Norton C, Bharucha AE. 2016. Management of opioid-induced constipation. Br J Nurs 25(10):S4-5, S8-11.

6. Nichols JW, Bae YH. 2014. EPR: Evidence and fallacy. J Control Release 190:451-464.

7. Maeda H, Wu J, Sawa T, Matsumura Y, Hori K. 2000. Tumor vascular permeability and the EPR effect in macromolecular therapeutics: a review. J Control Release 65(1-2):271-284.

8. Duncan R, Sat-Klopsch Y-N, Burger AM, Bibby MC, Fiebig HH, Sausville EA. 2013. Validation of tumour models for use in anticancer nanomedicine evaluation: the EPR effect and cathepsin B-mediated drug release rate. Cancer Chemother Pharmacol 72(2):417-427.

9. Maeda H. 2015. Toward a full understanding of the EPR effect in primary and metastatic tumors as well as issues related to its heterogeneity. Adv Drug Deliv Rev 91:3-6.

10. Greish K. 2007. Enhanced permeability and retention of macromolecular drugs in solid tumors: a royal gate for targeted anticancer nanomedicines. J Drug Target 15(7-8):457-464.

11. Friberg S, Nystrom AM. 2016. NANOMEDICINE: will it offer possibilities to overcome multiple drug resistance in cancer? J Nanobiotechnology 14:17.

12. Bregoli L, Movia D, Gavigan-Imedio JD, Lysaght J, Reynolds J, Prina-Mello A. 2016. Nanomedicine applied to translational oncology: A future perspective on cancer treatment. Nanomedicine 12(1):81-103. 
13. Rajora A, Ravishankar D, Osborn H, Greco F. 2014. Impact of the enhanced permeability and retention (EPR) effect and cathepsins levels on the activity of polymer-drug conjugates. Polymers 6(8):2186.

14. Stirland DL, Nichols JW, Miura S, Bae YH. 2013. Mind the gap: A survey of how cancer drug carriers are susceptible to the gap between research and practice. J Control Release. 172(3):1045-1064.

15. Stylianopoulos T, Jain RK. 2015. Design considerations for nanotherapeutics in oncology. Nanomedicine 11(8):1893-1907.

16. Fang J, Nakamura H, Maeda H. 2011. The EPR effect: Unique features of tumor blood vessels for drug delivery, factors involved, and limitations and augmentation of the effect. Adv Drug Deliv Rev 63(3):136-151.

17. Prabhakar U, Maeda H, Jain RK, Sevick-Muraca EM, Zamboni W, Farokhzad OC, Barry ST, Gabizon A, Grodzinski P, Blakey DC. 2013. Challenges and key considerations of the enhanced permeability and retention (EPR) effect for nanomedicine drug delivery in oncology. Cancer Res 73(8):2412-2417.

18. Maeda H, Matsumura Y. 2011. EPR effect based drug design and clinical outlook for enhanced cancer chemotherapy. Adv Drug Deliv Rev 63(3):129-130.

19. Koukourakis MI, Koukouraki S, Fezoulidis I, Kelekis N, Kyrias G, Archimandritis S, Karkavitsas N. 2000. High intratumoural accumulation of stealth ${ }^{\circ}$ liposomal doxorubicin (Caelyx ${ }^{\bullet}$ ) in glioblastomas and in metastatic brain tumours. Br J Cancer 83(10):1281-1286.

20. Zucchetti M, Boiardi A, Silvani A, Parisi I, Piccolrovazzi S, D'Incalci M. 1999. Distribution of daunorubicin and daunorubicinol in human glioma tumors after administration of liposomal daunorubicin. Cancer Chemother Pharmacol 44(2):173-176.

21. Albrecht KW, de Witt Hamer PC, Leenstra S, Bakker PJ, Beijnen JH, Troost D, Kaaijk P, Bosch AD. 2001. High concentration of Daunorubicin and Daunorubicinol in human malignant astrocytomas after systemic administration of liposomal Daunorubicin. J Neurooncol 53(3):267-271. 
22. Koukourakis MI, Koukouraki S, Giatromanolaki A, Archimandritis SC, Skarlatos J, Beroukas K, Bizakis JG, Retalis G, Karkavitsas N, Helidonis ES. 1999. Liposomal doxorubicin and conventionally fractionated radiotherapy in the treatment of locally advanced non-small-cell lung cancer and head and neck cancer. J Clin Oncol 17(11):3512-3521.

23. Harrington KJ, Mohammadtaghi S, Uster PS, Glass D, Peters AM, Vile RG, Stewart JSW. 2001. Effective targeting of solid tumors in patients with locally advanced cancers by radiolabeled pegylated liposomes. Clin Cancer Res 7(2):243-254.

24. Vasey PA, Kaye SB, Morrison R, Twelves C, Wilson P, Duncan R, Thomson AH, Murray LS, Hilditch TE, Murray T, Burtles S, Fraier D, Frigerio E, Cassidy J. 1999. Phase I clinical and pharmacokinetic study of PK1 [N-(2-Hydroxypropyl)methacrylamide copolymer doxorubicin]: First member of a new class of chemotherapeutic agents-drug-polymer conjugates. Clin Cancer Res 5(1):8394.

25. Gabizon A, Catane R, Uziely B, Kaufman B, Safra T, Cohen R, Martin F, Huang A, Barenholz Y. 1994. Prolonged circulation time and enhanced accumulation in malignant exudates of doxorubicin encapsulated in polyethylene-glycol coated liposomes. Cancer Res 54(4):987-992.

26. Seymour LW, Ferry DR, Kerr DJ, Rea D, Whitlock M, Poyner R, Boivin C, Hesslewood S, Twelves C, Blackie R, Schatzlein A, Jodrell D, Bissett D, Calvert H, Lind M, Robbins A, Burtles S, Duncan R, Cassidy J. 2009. Phase II studies of polymer-doxorubicin (PK1, FCE28068) in the treatment of breast, lung and colorectal cancer. Int J Oncol 34(6):1629-1636.

27. Pires LA, Hegg R, Valduga CJ, Graziani SR, Rodrigues DG, Maranhão RC. 2008. Use of cholesterolrich nanoparticles that bind to lipoprotein receptors as a vehicle to paclitaxel in the treatment of breast cancer: pharmacokinetics, tumor uptake and a pilot clinical study. Cancer Chemother Pharmacol 63(2):281-287. 
28. Graziani SR, Igreja FAF, Hegg R, Meneghetti C, Brandizzi LI, Barboza R, Amâncio RF, Pinotti JA, Maranhão RC. 2002. Uptake of a cholesterol-rich emulsion by breast cancer. Gynecol Oncol 85(3):493497.

29. Libutti SK, Paciotti GF, Byrnes AA, Alexander HR, Gannon WE, Walker M, Seidel GD, Yuldasheva N, Tamarkin L. 2010. Phase I and pharmacokinetic studies of CYT-6091, a novel PEGylated colloidal gold-rhTNF nanomedicine. Clin Cancer Res 16(24):6139-6149.

30. Lopez-Berestein G, Kasi L, Rosenblum MG, Haynie T, Jahns M, Glenn H, Mehta R, Mavligit GM, Hersh EM. 1984. Clinical pharmacology of ${ }^{99 \mathrm{~m}}$ Tc-labeled liposomes in patients with cancer. Cancer Res $44(1): 375-378$.

31. Wente MN, Kleeff J, Büchler MW, Wanders J, Cheverton P, Langman S, Friess H. 2005. DE-310, a macromolecular prodrug of the topoisomerase-I-inhibitor exatecan (DX-8951), in patients with operable solid tumors. Invest New Drugs 23(4):339-347.

32. Arrieta O, Medina L-A, Estrada-Lobato E, Ramírez-Tirado L-A, Mendoza-García V-O, de la GarzaSalazar J. 2014. High liposomal doxorubicin tumour tissue distribution, as determined by radiopharmaceutical labelling with ${ }^{99 \mathrm{~m}} \mathrm{Tc}-\mathrm{LD}$, is associated with the response and survival of patients with unresectable pleural mesothelioma treated with a combination of liposomal doxorubicin and cisplatin. Cancer Chemother Pharmacol 74(1):211-215.

33. Arrieta Ó, Medina LA, Estrada-Lobato E, Hernández-Pedro N, Villanueva-Rodríguez G, MartínezBarrera L, Macedo EO, López-Rodríguez V, Motola-Kuba D, Corona-Cruz JF. 2012. First-line chemotherapy with liposomal doxorubicin plus cisplatin for patients with advanced malignant pleural mesothelioma: phase II trial. Br J Cancer 106(6):1027-1032.

34. Boulikas T, Stathopoulos GP, Volakakis N, Vougiouka M. 2005. Systemic Lipoplatin infusion results in preferential tumor uptake in human studies. Anticancer Res 25(4):3031-3039. 
35. Gabizon A, Chisin R, Amselem S, Druckmann S, Cohen R, Goren D, Fromer I, Peretz T, Sulkes A, Barenholz Y. 1991. Pharmacokinetic and imaging studies in patients receiving a formulation of liposomeassociated adriamycin. Br J Cancer 64(6):1125-1132.

36. Julyan PJ, Seymour LW, Ferry DR, Daryani S, Boivin CM, Doran J, David M, Anderson D, Christodoulou C, Young AM, Hesslewood S, Kerr DJ. 1999. Preliminary clinical study of the distribution of HPMA copolymers bearing doxorubicin and galactosamine. J Control Release 57(3):281-290.

37. Seymour LW, Ferry DR, Anderson D, Hesslewood S, Julyan PJ, Poyner R, Doran J, Young AM, Burtles S, Kerr DJ, for the cancer research campaign phase I/II clinical trials committee. 2002. Hepatic drug targeting: phase I evaluation of polymer-bound doxorubicin. J Clin Oncol 20(6):1668-1676.

38. Sarapa N, Britto MR, Speed W, Jannuzzo M, Breda M, James CA, Porro M, Rocchetti M, Wanders A, Mahteme H, Nygren P. 2003. Assessment of normal and tumor tissue uptake of MAG-CPT, a polymer-bound prodrug of camptothecin, in patients undergoing elective surgery for colorectal carcinoma. Cancer Chemother Pharmacol 52(5):424-430.

39. Harris KA, Harney E, Small EJ. 2002. Liposomal doxorubicin for the treatment of hormone-refractory prostate cancer. Clin Prostate Cancer 1(1):37-41.

40. Ades A, Carvalho JP, Graziani SR, Amancio RF, Souen JS, Pinotti JA, Maranhão RC. 2001. Uptake of a cholesterol-rich emulsion by neoplastic ovarian tissues. Gynecol Oncol 82(1):84-87.

41. Koukourakis MI, Koukouraki S, Giatromanolaki A, Kakolyris S, Georgoulias V, Velidaki A, Archimandritis S, Karkavitsas NN. 2000. High intratumoral accumulation of stealth liposomal doxorubicin in sarcomas--rationale for combination with radiotherapy. Acta Oncol 39(2):207-211. 42. Northfelt DW, Martin FJ, Working P, Volberding PA, Russell J, Newman M, Amantea MA, Kaplan LD. 1996. Doxorubicin encapsulated in liposomes containing surface-bound polyethylene glycol: pharmacokinetics, tumor localization, and safety in patients with AIDS-related Kaposi's sarcoma. J Clin Pharmacol 36(1):55-63.

43. Wilhelm S, Tavares AJ, Dai Q, Ohta S, Audet J, Dvorak HF, Chan WCW. 2016. Analysis of nanoparticle delivery to tumours. Nat Rev Materials 1:16014. 
44. Cekanova M, Rathore K. 2014. Animal models and therapeutic molecular targets of cancer: utility and limitations. Drug Des Devel Ther 8:1911-1921.

45. Bernsen HJ, Rijken PF, Hagemeier NE, van der Kogel AJ. 1999. A quantitative analysis of vascularization and perfusion of human glioma xenografts at different implantation sites. Microvasc Res 57(3):244-257.

46. Bae YH. 2009. Drug Targeting and Tumor Heterogeneity. J Control Release 133(1):2-3.

47. Maeda H, Nakamura H, Fang J. 2013. The EPR effect for macromolecular drug delivery to solid tumors: Improvement of tumor uptake, lowering of systemic toxicity, and distinct tumor imaging in vivo. Adv Drug Deliv Rev 65(1):71-79.

48. Maeda H. 2012. Vascular permeability in cancer and infection as related to macromolecular drug delivery, with emphasis on the EPR effect for tumor-selective drug targeting. Proc Jpn Acad Ser B Phys Biol Sci 88(3):53-71.

49. Harrington KJ, Rowlinson-Busza G, Syrigos KN, Abra RM, Uster PS, Peters AM, Stewart JSW. 2000. Influence of tumour size on uptake of ${ }^{111}$ In-DTPA-labelled pegylated liposomes in a human tumour xenograft model. Br J Cancer 83(5):684-688.

50. Heneweer C, Holland JP, Divilov V, Carlin S, Lewis JS. 2011. Magnitude of enhanced permeability and retention effect in tumors with different phenotypes: ${ }^{89} \mathrm{Zr}$-albumin as a Model System. J Nucl Med 52(4):625-633.

51. Brown JM, Giaccia AJ. 1998. The unique physiology of solid tumors: opportunities (and problems) for cancer therapy. Cancer Res 58(7):1408-1416.

52. Brown JM. 1999. The hypoxic cell: a target for selective cancer therapy--eighteenth Bruce F. Cain Memorial Award lecture. Cancer Res 59(23):5863-5870.

53. Brown JM, Wilson WR. 2004. Exploiting tumour hypoxia in cancer treatment. Nat Rev Cancer $4(6): 437-447$.

54. Huang D, Lan H, Liu F, Wang S, Chen X, Jin K, Mou X. 2015. Anti-angiogenesis or proangiogenesis for cancer treatment: focus on drug distribution. Int J Clin Exp Med 8(6):8369-8376. 
55. Brown LF, Berse B, Jackman RW, Tognazzi K, Manseau EJ, Dvorak HF, Senger DR. 1993. Increased expression of vascular permeability factor (vascular endothelial growth factor) and its receptors in kidney and bladder carcinomas. Am J Pathol 143(5):1255-1262.

56. Anderson H, Yap JT, Wells P, Miller MP, Propper D, Price P, Harris AL. 2003. Measurement of renal tumour and normal tissue perfusion using positron emission tomography in a phase II clinical trial of razoxane. Br J Cancer 89(2):262-267.

57. Gillies RJ, Schornack PA, Secomb TW, Raghunand N. 1999. Causes and effects of heterogeneous perfusion in tumors. Neoplasia 1(3):197-207.

58. d'Assignies G, Couvelard A, Bahrami S, Vullierme M-P, Hammel P, Hentic O, Sauvanet A, Bedossa P, Ruszniewski P, Vilgrain V. 2009. Pancreatic endocrine tumors: tumor blood flow assessed with perfusion CT reflects angiogenesis and correlates with prognostic factors1. Radiology 250(2):407-416. 59. Ma J, Waxman DJ. 2008. Combination of anti-angiogenesis with chemotherapy for more effective cancer treatment. Mol Cancer Ther 7(12):3670-3684.

60. Stapleton S, Milosevic M, Tannock IF, Allen C, Jaffray DA. 2015. The intra-tumoral relationship between microcirculation, interstitial fluid pressure and liposome accumulation. J Control Release 211:163-170.

61. Warmuth C, Gunther M, Zimmer C. 2003. Quantification of blood flow in brain tumors: comparison of arterial spin labeling and dynamic susceptibility-weighted contrast-enhanced MR imaging. Radiology 228(2):523-532.

62. Mankoff DA, Dunnwald LK, Gralow JR, Ellis GK, Charlop A, Lawton TJ, Schubert EK, Tseng J, Livingston RB. 2002. Blood flow and metabolism in locally advanced breast cancer: relationship to response to therapy. J Nucl Med 43(4):500-509.

63. Delille J-P, Slanetz PJ, Yeh ED, Kopans DB, Garrido L. 2002. Breast Cancer: regional blood flow and blood volume measured with magnetic susceptibility-based MR imaging-Initial results. Radiology 223(2):558-565. 
64. Djuric-Stefanovic A, Saranovic D, Sobic-Saranovic D, Masulovic D, Artiko V. 2015. Standardized perfusion value of the esophageal carcinoma and its correlation with quantitative CT perfusion parameter values. Eur J Radiol 84(3):350-359.

65. Hayano K, Shuto K, Satoh A, Aoyagi T, Narushima K, Gunji H, Kono T, Yanagawa N, Okazumi S, Matsubara H. 2014. Tumor blood flow change measured by CT perfusion during chemoradiation therapy (CRT) for monitoring response and predicting survival in patients with esophageal cancer. Esophagus 11(1):72-79.

66. Yao J, Yang Z-g, Chen T-w, Li Y, Yang L. 2010. Perfusion changes in gastric adenocarcinoma: evaluation with 64-section MDCT. Abdom Imaging 35(2):195-202.

67. Komar G, Kauhanen S, Liukko K, Seppänen M, Kajander S, Ovaska J, Nuutila P, Minn H. 2009.

Decreased blood flow with increased metabolic activity: a novel sign of pancreatic tumor aggressiveness.

Clin Cancer Res 15(17):5511-5517.

68. Goh V, Glynne-Jones R. 2014. Perfusion CT imaging of colorectal cancer. Br J Radiol 87(1034):20130811.

69. Sahani DV, Kalva SP, Hamberg LM, Hahn PF, Willett CG, Saini S, Mueller PR, Lee TY. 2005. Assessing tumor perfusion and treatment response in rectal cancer with multisection CT: initial observations. Radiology 234(3):785-792.

70. Pober JS, Sessa WC. 2015. Inflammation and the blood microvascular system. Cold Spring Harb Perspect Biol 7(1):a016345.

71. Sun C, Jain RK, Munn LL. 2007. Non-uniform plasma leakage affects local hematocrit and blood flow: implications for inflammation and tumor perfusion. Ann Biomed Eng 35(12):2121-2129.

72. Dvorak HF. 2015. Tumors: wounds that do not heal-redux. Cancer Immunol Res 3(1):1-11.

73. Nesteruk M, Lang S, Veit-Haibach P, Studer G, Stieb S, Glatz S, Hemmatazad H, Ikenberg K, Huber G, Pruschy M, Guckenberger M, Klock S, Riesterer O. 2015. Tumor stage, tumor site and HPV dependent correlation of perfusion CT parameters and [18F]-FDG uptake in head and neck squamous cell carcinoma. Radiother Oncol 117(1):125-131. 
74. Awasthi VD, Goins B, Klipper R, Phillips WT. 2002. Accumulation of PEG-liposomes in the inflamed colon of rats: potential for therapeutic and diagnostic targeting of inflammatory bowel diseases. J Drug Target 10(5):419-427.

75. Hirai M, Minematsu H, Kondo N, Oie K, Igarashi K, Yamazaki N. 2007. Accumulation of liposome with Sialyl Lewis $\mathrm{X}$ to inflammation and tumor region: application to in vivo bio-imaging. Biochem Biophys Res Commun 353(3):553-558.

76. Boerman OC, Storm G, Oyen WJ, van Bloois L, van der Meer JW, Claessens RA, Crommelin DJ, Corstens FH. 1995. Sterically stabilized liposomes labeled with indium-111 to image focal infection. J Nucl Med 36(9):1639-1644.

77. Kumar Khanna V. 2012. Targeted Delivery of Nanomedicines. ISRN Pharmacol 2012:571394.

78. Kou L, Sun J, Zhai Y, He Z. 2013. The endocytosis and intracellular fate of nanomedicines: Implication for rational design. Asian Journal of Pharmaceutical Sciences 8(1):1-10.

79. Kobayashi H, Turkbey B, Watanabe R, Choyke PL. 2014. Cancer Drug Delivery: Considerations in the Rational Design of Nanosized Bioconjugates. Bioconjug Chem 25(12):2093-2100.

80. Jain V, Jain S, Mahajan SC. 2015. Nanomedicines based drug delivery systems for anti-cancer targeting and treatment. Curr Drug Deliv 12(2):177-191.

81. Moss DM, Siccardi M. 2014. Optimizing nanomedicine pharmacokinetics using physiologically based pharmacokinetics modelling. Br J Pharmacol 171(17):3963-3979.

82. Lane LA, Qian X, Smith AM, Nie S. 2015. Physical chemistry of nanomedicine: understanding the complex behaviors of nanoparticles in vivo. Annu Rev Phys Chem 66:521-547. 
Figures and Tables:

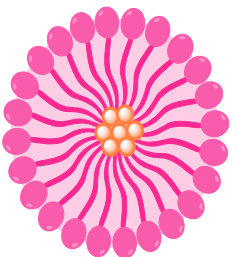

Polymeric micelles

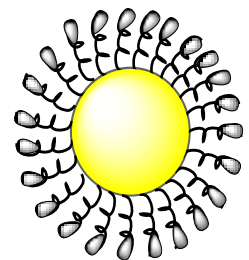

Metal nanoparticles

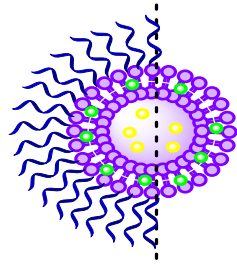

Liposomes

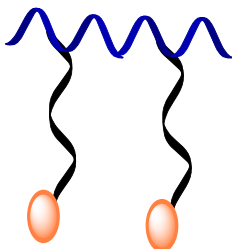

Polymer-drug conjugates

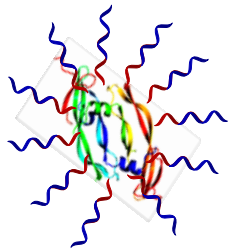

Polymer-protein conjugates

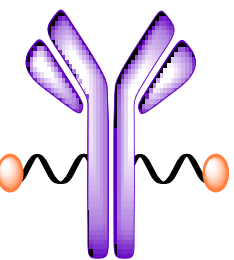

Antibody-drug conjugates

Figure 1. Schematic representation of examples of nanomedicines used to treat cancer. 

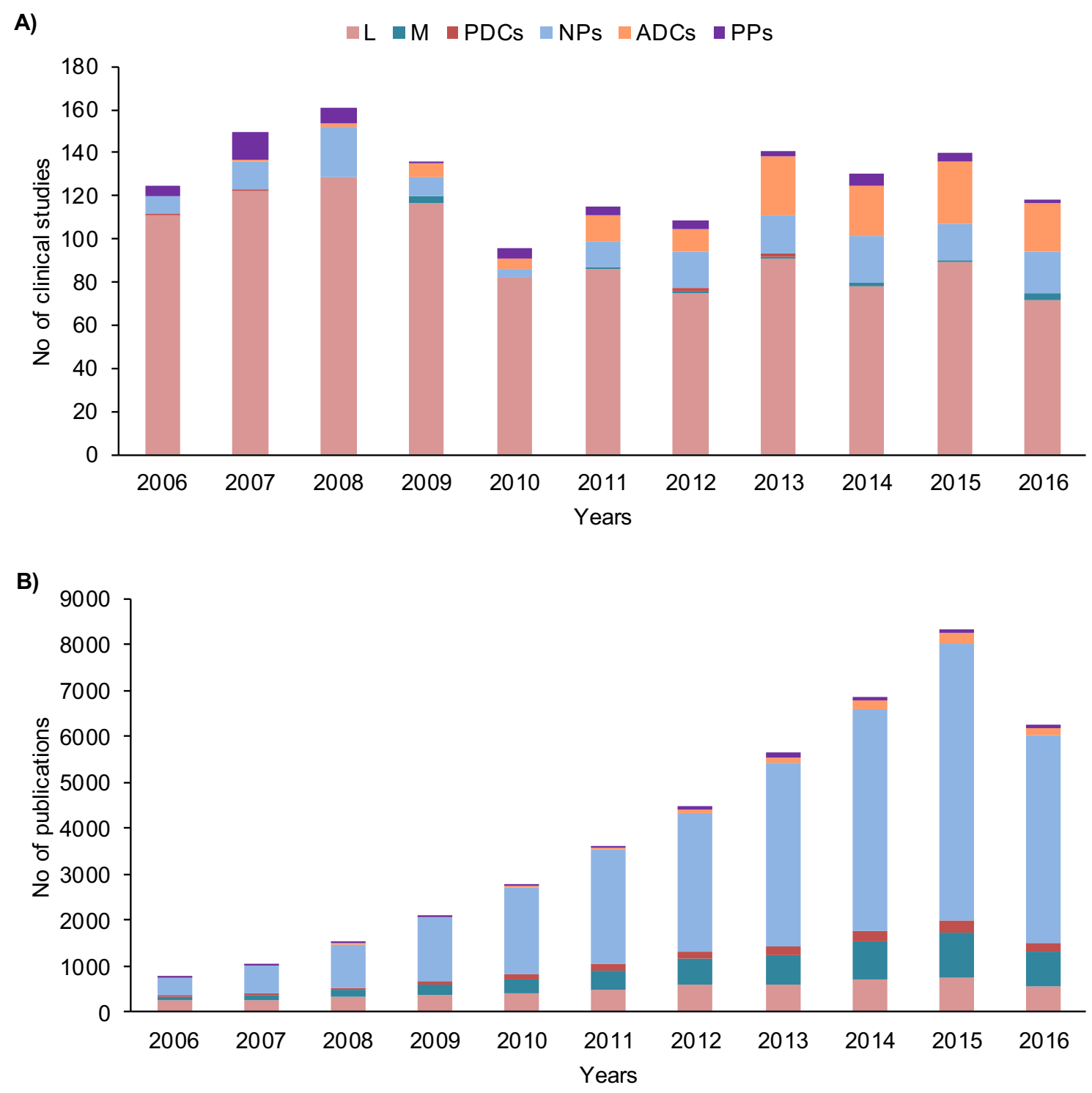

Figure 2. The number of clinical trials and publications of different nanomedicines (L: liposomes; M: micelles; PDCs: polymer-drug conjugates; NPs: nanoparticles; ADCs: antibody-drug conjugates; PPs: PEGylated proteins) in the last 10 years. A) Number of clinical trials of different nanomedicines investigated as anticancer agents (clinicaltrails.gov). B) Number of publications (Web of Science ${ }^{\circledR}$ ) in the area of nanomedicines for cancer (September 2016). Data indicate number of publications retrieved searching: "liposomes and cancer" (pink); "micelles and cancer" (teal); "polymer-drug conjugates and cancer" (dark red); "nanoparticles and cancer" (light blue); "antibody-drug conjugates and cancer" (orange); "PEGylated proteins and cancer" (violet). 


\section{Articles identified through database search}

Search engines: Web of Science, Science Direct, Pubmed. Search performed: 1 keyword form A and 1 keyword B (all possible combinations).

Keyword A: "liposome"; "polymer-drug conjugate"; "macromolecular prodrug"; "macromolecular conjugate"; "polymer based prodrug"; "polymer based conjugate"; "micelle"; "pegylated protein"; "nanoparticle".

Keyword B: "accumulation"; "distribution"; "intratumral”; "uptake".

Inclusion criteria: studies relating to:

- Nanomedicines

$$
\text { And }
$$

- Clinical studies

$$
\text { And }
$$

- Solid tumors

$$
\text { And }
$$

- Qualitative and quantitative evaluation of tumor contents of nanomedicines.

Figure 3. Flowchart summarizing the method employed for article selection in this study. 


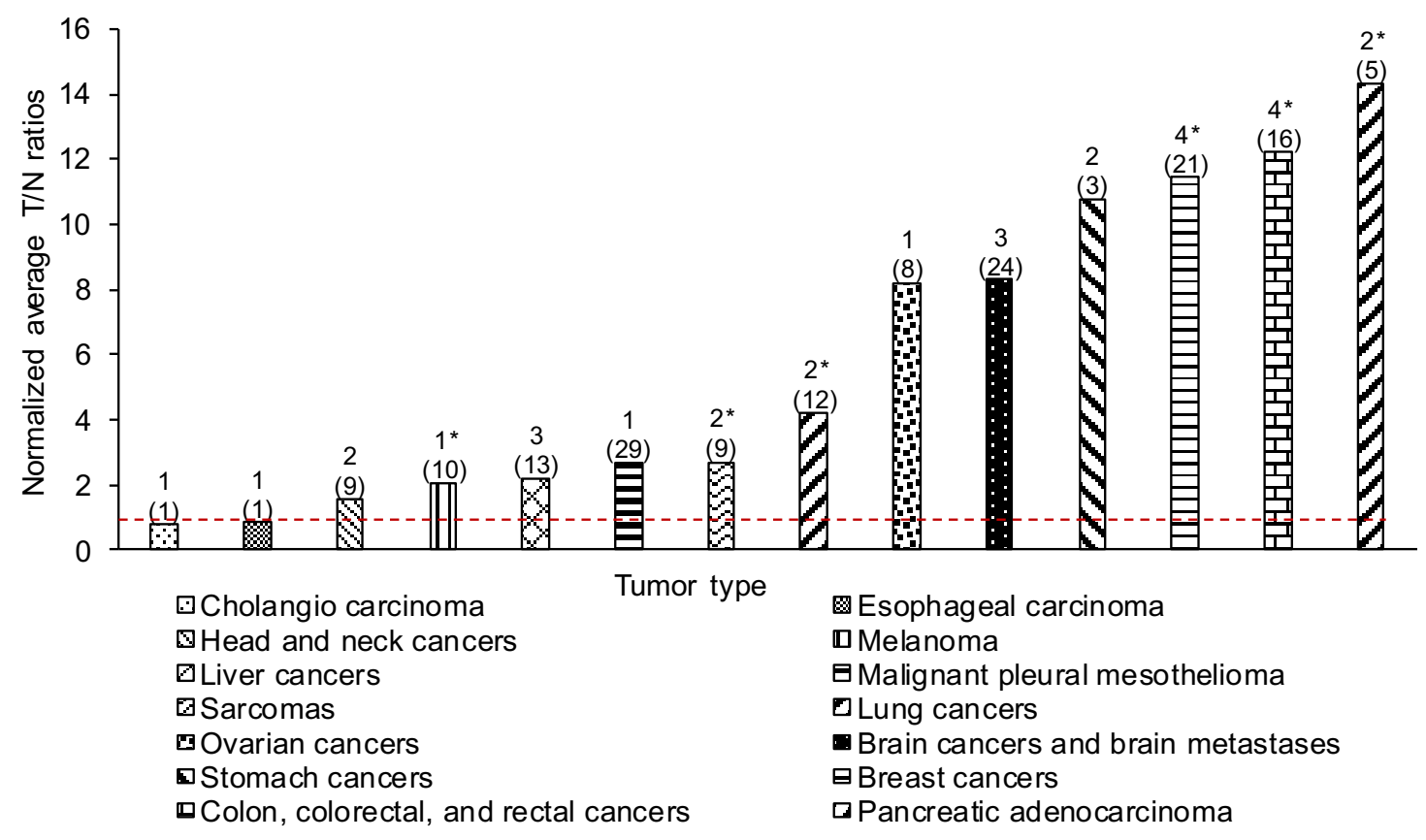

Figure 4. Normalized average $\mathrm{T} / \mathrm{N}$ ratios of different nanomedicines accumulated in different tumors. The number between parentheses indicates the total number of evaluated patients, and the number above parentheses indicates the number of clinical studies of an individual tumor. *: In one study ${ }^{29}$, detection of nanoparticles (NPs) was lower than the limit of detection. In those cases, the presence of NPs in normal tissues was arbitrarily set at the limit of detection (i.e. the lowest number of NPs that could be detected). The red line indicates $\mathrm{T} / \mathrm{N}$ ratio of 1 (i.e. columns above the red lines had a degree of preferential accumulation in the tumor). 
A)

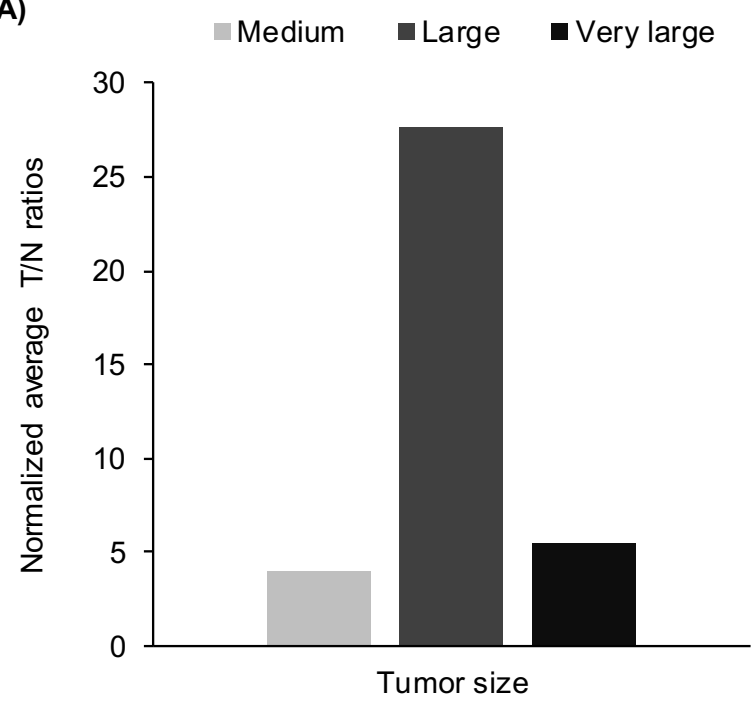

B)

$\square$ Medium $\quad \square$ Large $\quad$ Very large

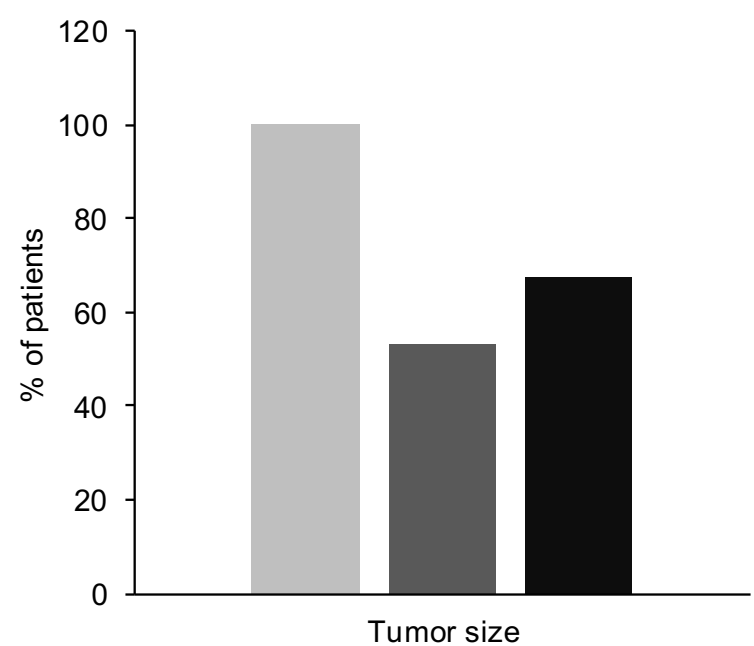

Figure 5. The effect of tumor size on the EPR effect ${ }^{19-23,26-29,31,33,34,36-38,40,41}$. A) Normalized average T/N ratios of different nanomedicines accumulated in tumors according to tumors size. B) \% of patients in each tumor size category who have $\mathrm{T} / \mathrm{N}$ ratio $\geq 2$. 
A)

Adequate blood supply

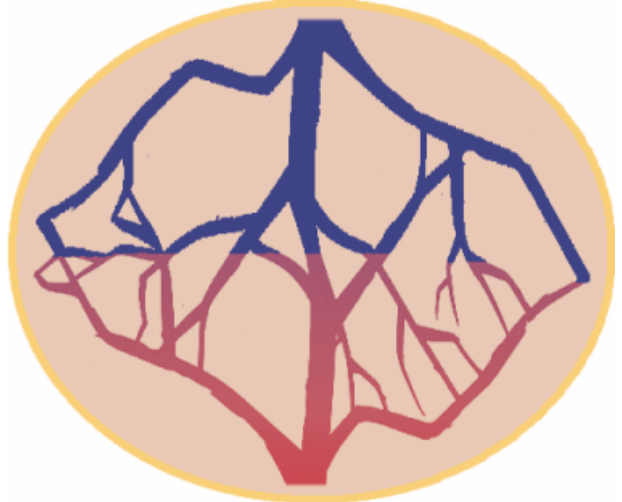

Blood perfusion in normal tissues

B)

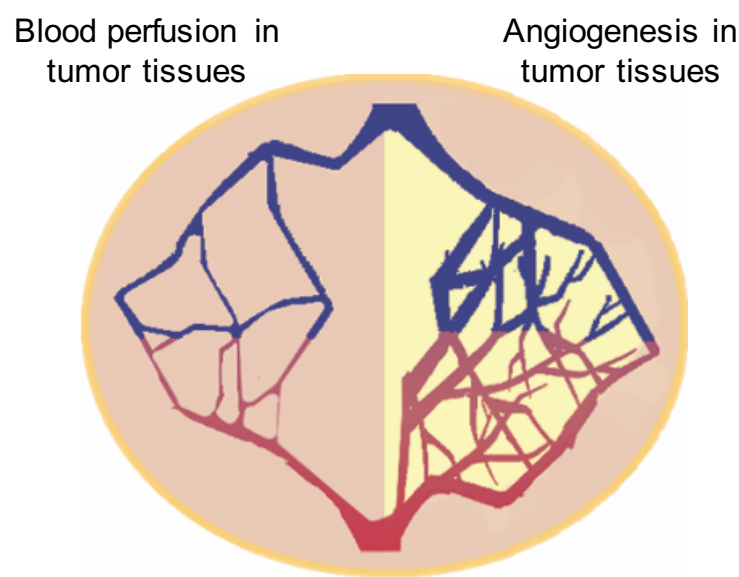

Blood perfusion in tumor tissues

Figure 6. Blood perfusion patterns in normal and tumor tissues. A) In normal tissues, the normal vasculature maintains their adequate blood perfusion. B) The heterogeneity of blood vasculature in tumor tissues results in areas with poor blood perfusion and areas with newly formed blood vessels (angiogenesis). 
Steps of a nanomedicine to have a therapeutic effect

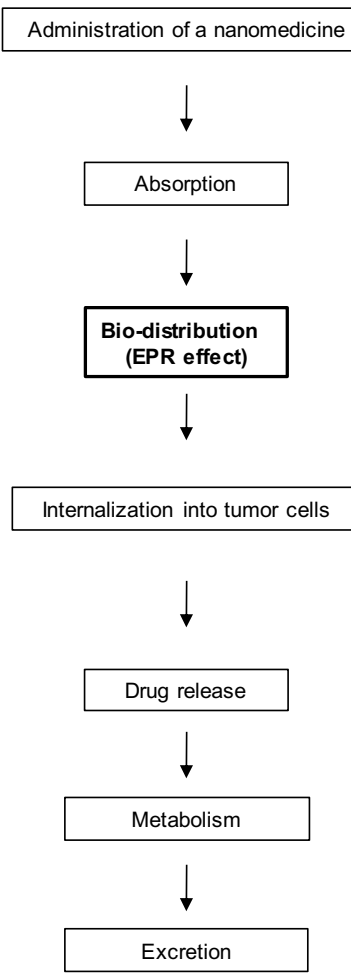

Associated considerations/challenges

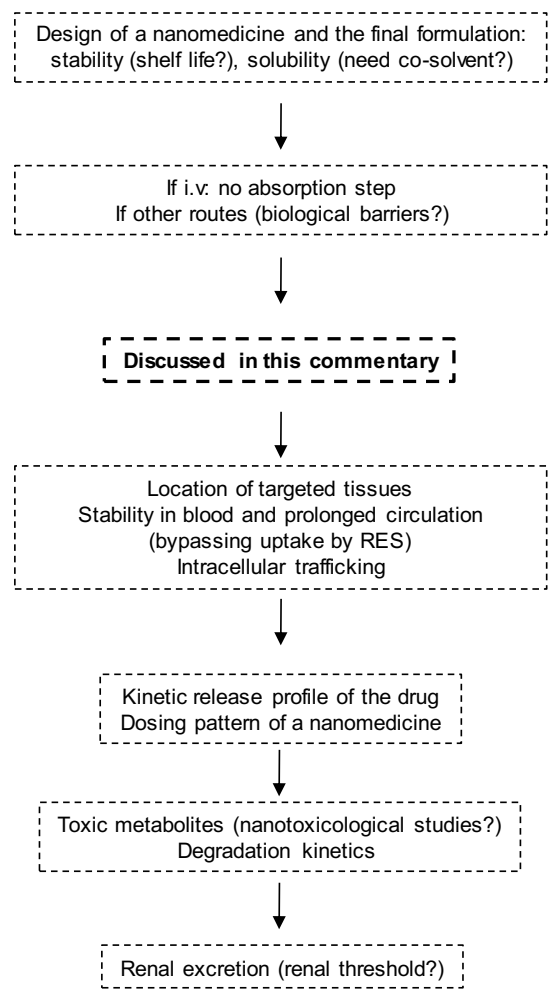

Figure 7. Factors influencing the clinical outcomes of a nanomedicine. ${ }^{77-82}$ RES: reticuloendothelial system (kidneys, spleen, and liver). 
a)

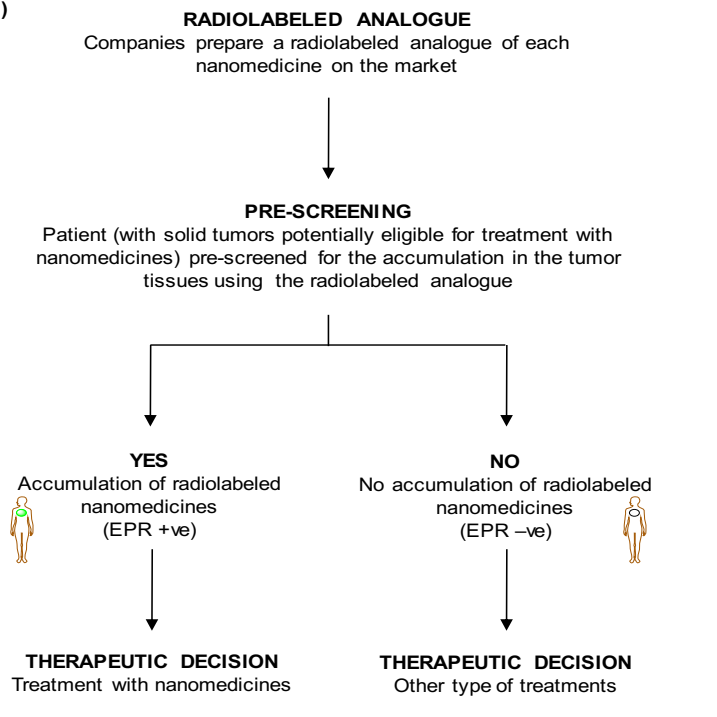

b)

ADDITIONAL STUDIES

Studies for identifying biomarkers for the EPR effect

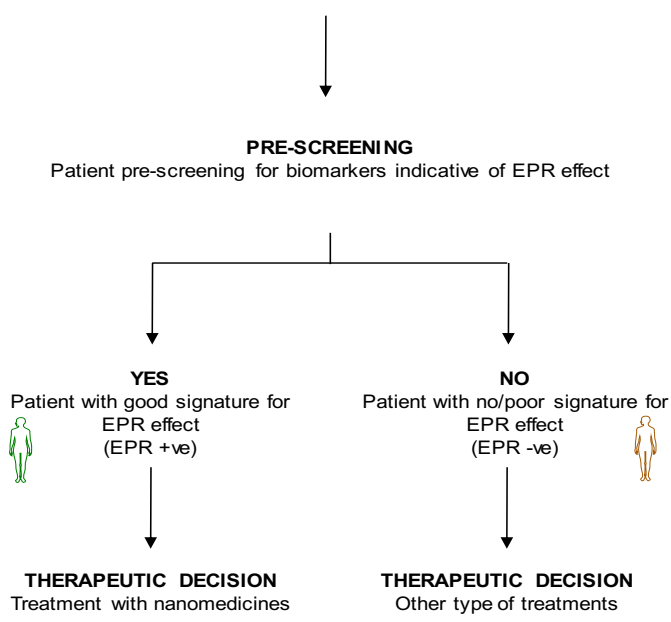

Figure 8. Proposed future strategy for a proper pre-selection of patients for effective treatment with nanomedicines. A) Screening of the accumulation of labeled nanomedicines administered in groups of patients (individually) to identify patients to be treated with nanomedicines. B) Identification and screening of specific biomarkers among patients to determine patients (individually) to be treated with nanomedicines. 
Table 1. A summary of available clinical data about the variations in tumor perfusion according to tumor types, size, stage, and location.

\begin{tabular}{|c|c|c|c|c|c|}
\hline $\begin{array}{l}\text { Tumor } \\
\text { Type }\end{array}$ & $\begin{array}{c}\text { Tumor stage, size, or } \\
\text { location }\end{array}$ & $\begin{array}{l}\text { Blood flow in } \\
\text { tumor tissue }\end{array}$ & $\begin{array}{l}\text { Blood flow in } \\
\text { normal tissue }\end{array}$ & $\begin{array}{l}\mathrm{T} / \mathrm{N} \\
\text { blood } \\
\text { flow } \\
\text { ratio }\end{array}$ & Ref \\
\hline \multirow{3}{*}{$\begin{array}{l}\text { Brain } \\
\text { cancers } \\
\text { and brain } \\
\text { metastasis }\end{array}$} & Untreated glioma stage I & $\begin{array}{c}44.3 \pm 9 \\
\mathrm{~mL} / 100 \mathrm{~g} / \mathrm{min} *\end{array}$ & $\begin{array}{c}95.3 \pm 41 \\
\mathrm{~mL} / 100 \mathrm{~g} / \mathrm{min} *\end{array}$ & 0.53 & \\
\hline & Untreated glioma stage II & $\begin{array}{c}48 \pm 10.6 \\
\mathrm{~mL} / 100 \mathrm{~g} / \mathrm{min} *\end{array}$ & $\begin{array}{c}68 \pm 12.2 \\
\mathrm{~mL} / 100 \mathrm{~g} / \mathrm{min} *\end{array}$ & 0.7 & 61 \\
\hline & $\begin{array}{l}\text { Untreated glioma stage III, } \\
\text { IV, and metastases }\end{array}$ & $\begin{array}{c}107.9 \pm 57.39 \\
\mathrm{~mL} / 100 \mathrm{~g} / \mathrm{min} *\end{array}$ & $\begin{array}{c}70.3 \pm 20.6 \\
\mathrm{~mL} / 100 \mathrm{~g} / \mathrm{min}^{*}\end{array}$ & 1.56 & 61 \\
\hline \multirow{2}{*}{$\begin{array}{l}\text { Breast } \\
\text { cancers }\end{array}$} & NA & $0.32 \mathrm{~mL} / \mathrm{g} / \mathrm{min}$ & $0.06 \mathrm{~mL} / \mathrm{g} / \mathrm{min}$ & 5.33 & $\overline{62}$ \\
\hline & 1/III, 2/III, 3 /III & $5.1 \pm 2.8^{* a}$ & $1.28 \pm 0.5^{* a}$ & 4.46 & 63 \\
\hline \multirow[t]{2}{*}{$\begin{array}{l}\text { Esophageal } \\
\text { cancer }\end{array}$} & $\begin{array}{l}\text { Different stages with T2, } \\
\text { T3, T4, N0, N1, N2, N3, } \\
\text { M0, M1. } \\
\text { Tumor length range }(3-15 \\
\mathrm{cm}) \text { and median }=6.75 \mathrm{~cm} . \\
\text { Tumor volume range }(10- \\
182 \mathrm{ml}) \text { and median }=31 \\
\text { ml. }\end{array}$ & $77.5 \mathrm{ml} / 100 \mathrm{~g} / \mathrm{min}$ & $14.8 \mathrm{ml} / 100 \mathrm{~g} / \mathrm{min}^{b}$ & 5.23 & 64 \\
\hline & $\begin{array}{c}\text { Different stages with T3, } \\
\text { T4, N0, N1. Tumor size } \\
\text { range }(30-190 \mathrm{~mm}) \text { and } \\
\text { median }=67.5 \mathrm{~mm} \\
\end{array}$ & $\begin{array}{c}72.4 \pm 47.8 \mathrm{ml} / 100 \\
\mathrm{~g} / \mathrm{min}^{*}\end{array}$ & NA & - & 65 \\
\hline \multirow[t]{8}{*}{$\begin{array}{l}\text { Gastric } \\
\text { cancers }\end{array}$} & Cardia & $\begin{array}{c}28.9 \pm 11.5 \mathrm{~mL} / 100 \\
\mathrm{~g} / \mathrm{min} *\end{array}$ & $\begin{array}{c}24.6 \pm 20.9 \mathrm{~mL} / 100 \\
\mathrm{~g} / \mathrm{min} *\end{array}$ & 1.17 & 66 \\
\hline & Body & $\begin{array}{c}31.7 \pm 19.6 \mathrm{~mL} / 100 \\
\mathrm{~g} / \mathrm{min}^{*}\end{array}$ & $\begin{array}{c}41 \pm 30.3 \mathrm{~mL} / 100 \\
\mathrm{~g} / \mathrm{min}^{*}\end{array}$ & 0.77 & 66 \\
\hline & Antrum and pylorus & $\begin{array}{c}28 \pm 15 \mathrm{~mL} / 100 \\
\mathrm{~g} / \mathrm{min} *\end{array}$ & $\begin{array}{c}30.4 \pm 14.4 \mathrm{~mL} / 100 \\
\mathrm{~g} / \mathrm{min} *\end{array}$ & 0.92 & 66 \\
\hline & Whole stomach & $\begin{array}{c}30.3 \pm 14.9 \mathrm{~mL} / 100 \\
\mathrm{~g} / \mathrm{min}^{*}\end{array}$ & $\begin{array}{c}32.9 \pm 25.7 \mathrm{~mL} / 100 \\
\mathrm{~g} / \mathrm{min}^{*}\end{array}$ & 0.92 & 66 \\
\hline & $\begin{array}{c}\text { Tumor with lymph node } \\
\text { metastases }\end{array}$ & $\begin{array}{c}30.7 \pm 12.4 \mathrm{~mL} / 100 \\
\mathrm{~g} / \mathrm{min}^{*}\end{array}$ & $32.2 \mathrm{~mL} / 100 \mathrm{~g} / \mathrm{min}$ & 0.95 & 66 \\
\hline & $\begin{array}{c}\text { Tumor without lymph node } \\
\text { metastases }\end{array}$ & $\begin{array}{c}31.1 \pm 21.4 \mathrm{~mL} / 100 \\
\mathrm{~g} / \mathrm{min}^{*}\end{array}$ & $32.2 \mathrm{~mL} / 100 \mathrm{~g} / \mathrm{min}$ & 0.96 & 66 \\
\hline & Early stage tumors & $\begin{array}{c}30.1 \pm 29.2 \mathrm{~mL} / 100 \\
\mathrm{~g} / \mathrm{min}^{*}\end{array}$ & $32.2 \mathrm{~mL} / 100 \mathrm{~g} / \mathrm{min}$ & 0.93 & 66 \\
\hline & Advanced stage tumors & $\begin{array}{c}30.9 \pm 13.3 \mathrm{~mL} / 100 \\
\mathrm{~g} / \mathrm{min}^{*}\end{array}$ & $32.2 \mathrm{~mL} / 100 \mathrm{~g} / \mathrm{min}$ & 0.96 & 66 \\
\hline \multirow[t]{3}{*}{$\begin{array}{l}\text { Pancreatic } \\
\text { cancers }\end{array}$} & $\begin{array}{c}\text { Tumor classification: WHO } \\
1\end{array}$ & $284 \mathrm{~mL} / 100 \mathrm{~g} / \mathrm{min}$ & $130.4 \mathrm{~mL} / 100 \mathrm{~g} / \mathrm{min}$ & 2.18 & 58 \\
\hline & $\begin{array}{c}\text { Tumor classification: WHO } \\
2\end{array}$ & $229.1 \mathrm{~mL} / 100 \mathrm{~g} / \mathrm{min}$ & $130.4 \mathrm{~mL} / 100 \mathrm{~g} / \mathrm{min}$ & 1.75 & 58 \\
\hline & Tumor classification: WHO & $153.5 \mathrm{~mL} / 100 \mathrm{~g} / \mathrm{min}$ & $130.4 \mathrm{~mL} / 100 \mathrm{~g} / \mathrm{min}$ & 1.18 & 58 \\
\hline
\end{tabular}




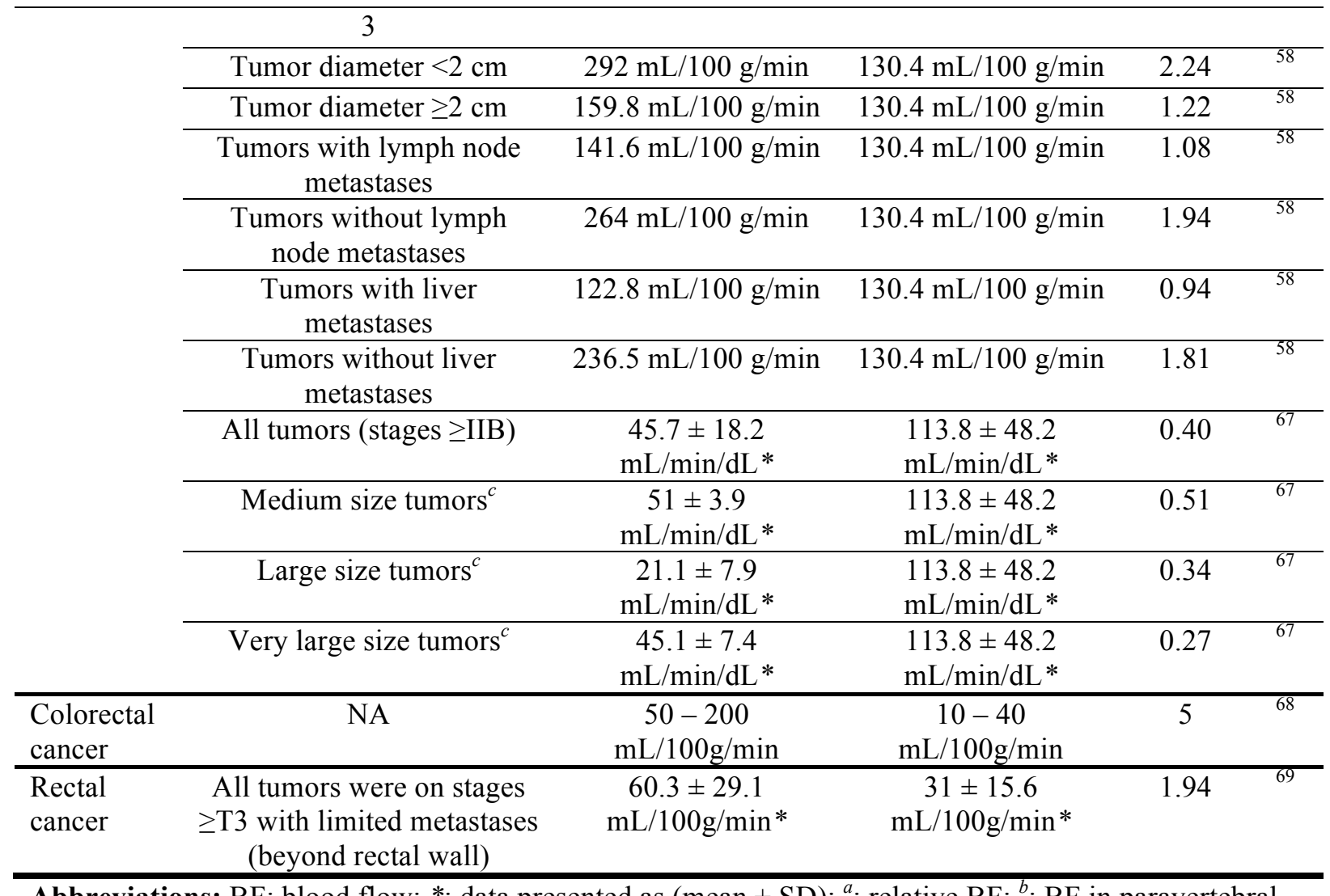

Abbreviations: BF: blood flow; *: data presented as (mean $\pm \mathrm{SD}){ }^{a}{ }^{\text {: }}$ relative $\mathrm{BF} ;{ }^{b}: \mathrm{BF}$ in paravertebral skeletal muscles; ${ }^{c}$ : data calculated for tumors with identified stage. The size of tumors was considered as medium if tumors were on stage IIB or with low grade NET, as large if tumors were on stage III, and as very large if tumors were on stage IV or with high grade NET. 